\title{
Transportation System Organized Within a Function of a Modern Tourism Development
}

\author{
LJILJANA B. RADULOVIĆ, Tesla payments, Pennsylvania, USA
}

\author{
Original scientific paper
}

$U D C: 656.07$

DOI: 10.5937/tehnika1805691R

\begin{abstract}
The evolution of transport market conditions strengthened by dynamic development of technology and increased demands for transport services compels for an improved strategic methodological and analytical concept aimed at establishing a transportation system that will ensure the necessary compliance factors including: safety, efficiency and spatio-temporal harmony, all required for successful establishment of tourist destinations availability and positioning in the modern tourism marketplace. To this end, the conducted research aims to identify the degree of interdependence between the development of transport and tourism based on the analysis of theoretical concepts and defined dimensions of modern transportation system in order to emphasize main hallmarks of the modern transport and tourism market in the process of establishing a transportation system organized in the function of a modern tourism development.
\end{abstract}

Key words: destination, concept, transport, system, tourism, market

\section{INTRODUCTION}

Development of a complex transportation system with a high degree of coordination and efficiency would result in a competitive tourist services and establishment of a sustainable modern tourism market.

Establishing such system would require a continuous analysis of numerous parameters of the modern tourism market and identified developmental market tendencies in order to determine the basic dimensions and efficient measures organized in the function of establishing a stable, wider integrated and economically stimulating transportation system.

\section{INTERDEPENDENCE BETWEEN TOURISM DEVELOPMENT AND TRANSPORTATION SYSTEM}

Identifying the degree of interdependence between the development of transport and tourism through the historically observed contribution of the transport network expansion and the modernized modes of transport towards the growth of tourism on an internati-

Author's address: Ljiljana Radulović, 830 Montgomery Ave, apt 115, Bryn Mawr, PA 19010, United States of America

e-mail: ljiljanaradulovic.pg@gmail.com

Paper received: 20.08.2018.

Paper accepted: 27.08.2018. onal scale relies on understanding the interaction of numerous components and analysis of theoretical postulates which emphasize the importance of transport as an integral part of the tourism industry which would ultimately provide competitive positioning of tourist destinations [1].

The genesis and main experiences of certain developmental periods determine transport to be the initiator of tourism trends and factor of the international tourism development.

Based on social, technological and economic progress and the established level and development pace of individual modes of transport, according to which the organizational scheme of the transportation system was adapted, transportation system provided the necessary accessibility of tourist destinations and resulted in a high degree of interdependence between the development of the transport and international tourism market.

Apart from the significant impact of transport growth on global tourism trends, prominent influence has been identified on the expansion of the international tourism market to the increase in demand for transport services, which directly and indirectly influenced the expansion of the transport network and the improvement of the international transport market.

Considering the fact that transport services account for almost $20 \%$ of total tourism consumption [2], 
conducted research identified high degree of interaction between transport and tourism market and classifies transportation as a dynamic system functioning within a specific environment and initiates structural transformations. This process requires significant adaptations to accomodate formation of the transport chain and effective organization of the transport infrastructure.

To this end, further research is focused on identifying theoretical concepts where the transport functions as a subsystem component within larger tourism system.

\section{THEORETICAL CONCEPTS OF A MODERN TRANSPORTATION SYSTEM}

The structure of individual transportation systems based on the determined structure of demand for transport services, according to which the organizational concept is created and new capacity for supply of transport, ultimately influences the choice of travel mode and defines the degree of representation and development of certain types of transport. In light of this, demand is recognized to re-define and put forward concepts of the transportation system that determine the modern transport market.

An integrated concept of the transportation system implies an organizational structure that incorporates services with an efficient transportation system based on time synchronization and provides availability and speed of travel, the safety and quality of transport services, which is why from the point of view of interaction and activity on tourism trends, the modern transportation system can be treated as a subsystem of the tourism integral system.

Therefore planning the development of the transportation system as a well-organized unit of tourist service requires a high degree of coordination with the complex requirements of modern tourism, organized as a function of competitive positioning in the modern transport and tourism market.

The concept of the modern transportation system is based on the organizational structure that determines tourism as a complex system, in accordance with the interaction of many subsystems whose services differ in character and time component but with the common characteristic of the necessary spatial and temporal harmonization. An adequate and efficient degree of synchronization of the subsystem based on the unified contemporary processes determines the quality of tourist services, which according to the modern concept requires the establishment of efficient coordination of all forms of transport and identified conditionality of the modern transportation subsystem as an inevitable and crucial part of the tourism system.
The future concept of the transportation system entails a framework which aims to maximize quantitative and qualitative parameters based on the timely implementation of technological achievements and innovations of the modern society, which will ensure efficient improvement of the transportation systems organized in the function of the continuous development of modern tourism.

\section{KEY DIMENSIONS OF A MODERN TRANSPORTATION SYSTEM}

Modern transportation system is distinguished by a three-dimensional character created as a result of the interconnectedness of the economic, sociological and ecological components, that is, the identified interactions with the transportation system [3].

The economic dimension of the transportation system is focused on economic prosperity in accordance with the determined transport setting as a subsystem of the tourism system whose development is supported by economic activities.

To this end, the economic progress requires commercial justification of the transportation system that will be treated as a crucial part of the modern tourism development policy.

Additionally, transportation system is essential element for social development that is economically viable and financially accessible while also putting forth adequate efficient organizational and safety measures. As such, transportation system initiates the development of tourism in accordance with the requirements of the modern tourism market.

Sociological dimension of the transportation system implies equal development and participation of certain modes of transport, based on enhanced quality and competitive prices of transport services with an emphasis on safe transportation and preservation of basic components of quality of life.

Historical examples provided by the developed countries emphasize the importance of adequate treatment of the sociological dimension, which due to the complex character and high degree of dependence on political and economic stability, requires a comprehensive approach in shaping the activities and measures organized in the function of improving the transportation system, in accordance with the requirements of the modern transport and tourism market.

The ecological dimension of the transportation system is framed by a high degree of responsibility in relation to the basic aspects of the environment, which requires a focus on the development of the use of renewable resources and the preservation of ecological integrity. Considering adverse effects of a dynamic transport network expansion on the environment, the 
importance of the ecological dimension is particularly important and requires a balance between demands for transport services and the preservation of the basic ecological values of the environment.

Taking into acount that interaction of transport with economic, sociological and ecological dimensions manifests itself not just isolated but cumulative effects, we believe that only continuous monitoring and analysis of positive and negative indicators can illuminate adequate direction of development of the transportation system and long-term prosperity of the modern transport market. Observed from the point of view of the development of contemporary tourism, the identified dimensions determine the strategic direction of the development of the transportation system, which will limit the negative effects caused by the future expansion of the transport and tourism market according to the limits of sustainability.

\section{IDENTIFIED DEVELOPMENT TENDENCIES OF A MODERN TRANSPORTATION SYSTEMS}

Contemporary social trends exposed the need for transformation of modern transportation system which imply structural and organizational adjustment to the modern conditions of demand and business transport market arena. This resulted in the spread of liberalization and deregulation, as modern processes aimed at defining effective measures and activities that will reduce the level of subsidies and the influence of state institutions on the development of transport industry [4].

In this fashion, steep competition, lower prices and higher quality of transport services was initiated, that is, the modern development of transport companies and the high level of transport organization were encouraged in line with modern trends on the international transport market.

Numerous advantages of liberalization and deregulation of the transportation system have been identified, both by the transport organizers which established equal market conditions and benefits that can provide a wide range and high quality of transport services, as well as by transport consumers who enjoy diverse offering according to the available free time, desired quality and prices of transport services.

From the point of view of modern tourism development, the liberalization and deregulation of the transportation system has provided a greater flexibility and travel design in accordance with individual needs and opportunities, resulting in numerous benefits. All this was reflected primarily in the significant increase in the number of travels arrangements and the increase in the level of transport and tourism capacity [5].
Given that the transportation system is part of a modern market concept that involves more interest groups and requires the development of a long-term policy based on caracteristics and the demand for transport services [6], we have recognized the need to highlight the importance of technological progress as a factor that has been to a large extent determined by the current development of the transportation system and which is recognized as a key factor for the future improvement of the modern transport market.

Reflecting on the significant influence of the development and implementation of IT technology, which through the expansion of the transport network and the improvement of the transportation means provided a higher level of transport safety, overcoming large space with a significant increase in speed and lower cost of transportation services, which, according to the increased demand, determined the volume and the structure of today's transport market.

Advancements in technology generated improvements in global information exchange and travel arrangement models, which, in turn initiated structural changes in sales channels as ain integrated function of transport services to the demands of the modern transport market and with a high degree of coordination with the predicted trends in the modern tourism market [7]. In line with this, we emphasize that the last year was marked by a forecast highlighting tourism as the main growing factor in the world, with a relative growth rate of $4 \%$ by 2020 , a total of 1.6 billion international tourist arrivals, and a possible 50 million new jobs in the tourism industry [8].

Globalization, numerous advancements in techonology and high demenad for research are all trends in line with modern tourism but also have significant implications for the transportation system, which is why the need for continuous monitoring of relevant parameters of the modern market which define main goals and identify strategic measures for the development of a transportation system organized within a function of a modern tourism.

\section{STRATEGIC MEASURES FOR THE DEVELOPMENT OF A MODERN TRANSPORTATION SYSTEM}

Defining measures for the development of a modern transportation system is based upon the results of the PEST analysis of the modern transport market. The complexity of this strategic model entails comprehensive analysis of the macro environment and can affect the market dynamics whether by increasing competiveness or stagnation.

Timely identification of these trends can forecast future changes in the market, accelerate progress and 
identify directions of future actions.

Given that development and transport dynamics are directly dependent on political, economic, sociocultural and technological factors, which highlights susceptibility to numerous challenges and trends present in the modern transport market, we have recognized the need for analysis and prediction of the influence of the basic factors PEST model.

\section{Graphic overview 1. Outline of the PEST analysis of the modern transport market}

\begin{tabular}{l} 
Political Factors \\
Political environment \\
Traffic development policy \\
Legislative and legal policy \\
\hline Economical factors \\
Economic environment \\
Inflation rate and price policy \\
Traffic company status \\
\hline Socio-cultural factors \\
Level of living standard \\
The amount of free time \\
The degree of travel culture \\
\hline Technological factors \\
Development and implementation of IT technology \\
Efficiency of information exchange \\
Booking and payment models
\end{tabular}

Key factors such as global political and economic challenges have had a significant impact on the transport market over the last decades and due to their adverse effects, new reformation goals have been set to overcome the problem of the abolition of transport line, rising prices of travel services and the shutdown of numerous transport companies.

Identified socio-cultural factors of the modern transportation system can generate an impact on the transport market assuming that they are largely conditioned by events on the political and economic scene. We can also view them as factors conditioned by the values of a country-specific social culture, but with a recognized significant impact on the market for transport services.

Technological factors of the modern transportation system determine the speed and efficiency of the expansion of the transport network and regulate means, safety and cost of transport as well as the availability of travel arrangement business models.

From this perspective it is critical to implement innovative technological solutions organized to strengthen the competitive position of the transportation system in the modern transport market.

The conducted PEST analysis of the modern transport market underlined the impact of global political and economic challenges, socio-cultural and technological factors on the development of the transportation system, which emphasizes the need for continuous inspection of the macro environment in order to identify potential changes, interactions and influence on transport activity since these conditions may determine effective measures and activities directed towards the competitive positioning of the transportation system.

An overview of the implemented measures for the development of a modern transportation system:

- Development and establishment of a modern transportation system based on development policy complementary to transport policies of developed countries;

- Efficient and environmentally sound management of the transportation system, based on continuous monitoring and understanding of the market conditions of the modern transport market;

- Harmonization of all forms of transportation, based on identified development opportunities and organized in order to strengthen the competitive position of the total transport turnover;

- Integration of transport services in order to achieve a higher level of realization, organization and economic efficiency, supported by a higher level of safety and quality of transport in accordance with the assessments of the factors of the modern transport market.

From the point of view of modern tourism development, the importance of continuous monitoring of modern tourism flows will be emphasized, in order to ensure the necessary coordination of the transportation system with predicted trends in the modern tourism market.

\section{CONCLUSIONS}

The conducted research highlighted the significance of the development of the transportation system that will be distinguished by the high quality of transport services, the equal competitive conditions of transport operators and the high degree of integration of certain types of transportation.

This is based on continuous research of the modern transport market as a basic precondition for improving the development and modernization of the transportation system, implemented international technical and safety standards with the necessary liberalization and deregulation of the transport market.

Consequently, the importance of timely recognition of modern transport tendencies and problems of the transportation system, organized in the function of determining the strategic direction of activity as a 
modern model, which can provide rationalization of the transport processes and high quality of the transport services necessary for acquiring and improving the competitive position in the transport market will be emphasized.

Nevertheless, identifying adequate development methodologies and efficient strategic solutions for the improvement of the transportation system can be considered as a challenge, especially if the developed transportation system is characterized as one of the basic prerequisites for competitive positioning of tourist destinations [9], thus emphasizing the importance of continual improvement of the transport network, supported by innovative technological solutions and modern transportation means.

Additionally, if the quality of the tourist service is determined by the established degree of safety and efficiency of the transportation system, the importance of implementation of international quality standards in the design of transport services is emphasized, which, through participation in the process of transport of tourists, become an inseparable part of the tourist experience and factor of the competitive position of the tourist destination on the international tourism market. In that sense, the final conclusion follows the transportation system organized within a function of a modern development of tourism is determined as the concept of modern trends necessary for the future development and improvement of the transport and tourism market.

\section{REFERENCES}

[1] Lumsdon L, Page S. Tourism and Transport - Issues and Agenda for the New Millennium, Routledge, New York, 2004.

[2] Božić V, Novaković S. Ekonomija saobraćaja, Ekonomski Fakultet Beograd, Beograd, 2008.

[3] Matias A, Nijkamp P, Sarmento M. Tourism Economics - Impact Analysis, Physica-Verlag, Berlin Heidelberg, 2011.

[4] Rodrigue JP, Comtois C, Slack, B. The Geography of Transport System, $3^{\text {rd }}$ edition, New York, 2013.

[5] Dwyer L, Forsyth P, Dwyer W. Tourism Economics and Policy, Channel View Publications, New York, 2010.

[6] Vešović V. Strateški menadžment u saobraćaju, Fakultet za menadžment u saobraćaju i komunikacijama, Berane, 2009.

[7] Culpan R. International tourism model for developing economies- Annals of Tourism Research, Vol. 14, pp. 541-552, Pennsylvania State University, Harrisburg, Pennsylvania, 1987.

[8] Buhalis D, Costa C, Tourism Business Frontiers - consumers, products and industry, pp. 2, Elsevier, Oxford, 2006.

[9] Popesku J. Menadžment turističke destinacije, Univerzitet Singidunum, Beograd, 2011.

\section{REZIME}

\section{SAOBRAĆAJNI SISTEM ORGANIZOVAN U FUNKCIJI SAVREMENOG RAZVOJA TURIZMA}

Evolucija saobraćajnih tržišnih uslova podržana dinamičnim razvojem tehnologije i pojačanim zahtjevima za uslugama prevoza inicirala je potrebu za strateškim metodološkim i analitičkim konceptom usmjerenim ka uspostavljanju saobraćajnog sistema koji će stepenom bezbijednosti, efikasnosti $i$ organizacije obezbijediti neophodnu teritorijalnu i vremensku usklađenost, kao faktora koji determinišu dostupnost i pozicioniranje turističkih destinacija na savremenom turističkom tržištu. U tom cilju, sprovedeno istraživanje je usmjereno ka identifikovanju stepena međuzavisnosti razvoja saobraćaja i turizma, zasnovano na analizi teorijskih koncepata $i$ determinisanju osnovnih dimenzija savremenog saobraćajnog sistema, kako bi shodno karakteristikama savremenog saobraćajnog i turističkog tržišta istakli značaj uspostavljanja saobraćajnog sistema organizovanog u funkciji savremenog razvoja turizma.

Ključne reči: destinacija, koncept, saobraćaj, sistem, turizam, tržište 